
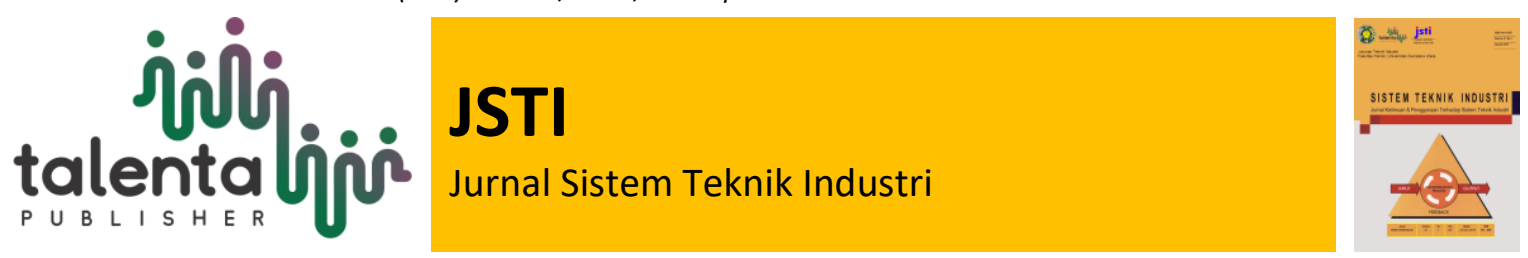

\title{
Penentuan Interval Waktu Perawatan Mesin Blowing dan Mesin Filling Menggunakan Teori Reliability dan Model Age Replacement (Studi Kasus pada PT. XYZ)
}

\author{
Ilyas Ruchiyat ${ }^{1)}$, Endang Prasetyaningsih ${ }^{2 *}$, Chaznin R. Muhammad ${ }^{3)}$ \\ 1),2),3) Prodi Teknik Industri, Fakultas Teknik, Universitas Islam Bandung
}

\begin{abstract}
Machine performance will decrease when it is operated continuously so that maintenance is needed. Improper maintenance time intervals will reduce machine reliability and the machine will damage suddenly. Therefore, maintenance time intervals must be determined precisely. This study aims to determine the maintenance time intervals using the Reliability Theory and Age Replacement Model, then calculate the total maintenance cost. In the case of PT XYZ, there are two machines that have the highest frequency of failure, i.e. Blowing machine with Sensitive Sensor as critical component, and Filling machine with Rell Capper as critical component. Computations show that the proposed maintenance time interval is 31 hours for the Sensitive Sensor component and 131 hours for the Rell Capper component. The maintenance of the two machines can be done separately or combined. Based on calculations, it is proposed that the 5th cycle of maintenance of the Blowing machine is carried out together with the Filling machine because it provides the highest reliability, even though it is not the cheapest. This combined treatment increases the reliability of Blowing machines by $26.2 \%$ and Filling machines by $44.1 \%$.
\end{abstract}

Keyword: Age replacement model, downtime, reliability

Abstrak. Performa mesin akan berkurang ketika dioperasikan terus menerus sehingga diperlukan perawatan. Interval waktu perawatan mesin yang tidak tepat dapat mengurangi keandalan mesin dan menyebabkan kerusakan mesin secara tiba-tiba. Oleh karena itu, interval waktu perawatan mesin harus ditentukan dengan tepat. Penelitian ini bertujuan untuk menentukan interval waktu perawatan mesin menggunakan Teori Reliability dan Model Age Replacement. Pada kasus PT XYZ, terdapat dua mesin yang memiliki frekuensi kerusakan tertinggi yaitu mesin Blowing dengan komponen kritis Sensor Sensitif, dan mesin Filling dengan komponen kritis Rell Capper. Perhitungan menunjukkan bahwa interval waktu perawatan usulan adalah 31 jam untuk komponen Sensor Sensitif dan 131 jam untuk komponen Rell Capper. Perawatan kedua mesin dapat dilakukan secara terpisah atau digabung. Berdasarkan perhitungan, diusulkan bahwa perawatan mesin Filling pada siklus ke-5 dimajukan dan dilakukan bersama-sama dengan mesin Filling karena memberikan keandalan paling tinggi, walaupun biayanya bukan yang paling murah. Gabungan perawatan ini dapat meningkatkan keandalan mesin Blowing sebesar 26,2\% dan mesin Filling sebesar 45,21\%.

Kata Kunci: Age replacement, downtime, keandalan

Received 15 April 2020 | Revised 25 April 2020 | Accepted 20 Mei 2020

*Corresponding author at: Jl. Tamansari No.1 Bandung 40116, Indonesia

E-mail address: endangpras@gmail.com

Copyright (C 2020 Published by Talenta Publisher, ISSN: 1411-5247 e-ISSN: 2527-9408

Journal Homepage: http://talenta.usu.ac.id/jsti 


\section{Pendahuluan}

PT. XYZ merupakan industri air minum dalam kemasan (AMDK) yang memproduksi dua jenis produk, yaitu AMDK gallon dan AMDK $600 \mathrm{ml}$. Masing-masing produk diproses di lini produksi yang berbeda, yaitu lini produksi House of Distribution (HOD) untuk memproduksi AMDK gallon dan lini produksi Small Packaging Size (SPS) untuk memproduksi AMDK 600 ml. Mesinmesin yang berada di lini produksi SPS sering mengalami kerusakan dan menyebabkan terjadinya breakdown, walaupun perusahaan sudah melakukan perawatan mesin secara berkala. Berdasarkan observasi, diperoleh informasi bahwa dalam 4 bulan (bulan Januari - April 2019) mesin Blowing, salah satu mesin pada lini produksi SPS, mengalami breakdown sebanyak 160 kali. Hal ini menunjukkan bahwa interval waktu perawatan yang ditentukan oleh perusahaan perlu diperbaiki untuk mengurangi terjadinya breakdown.

Breakdown berkaitan dengan keandalan (reliability). Semakin sering mesin mengalami breakdown, semakin rendah keandalannya. Breakdown dapat dicegah dengan melakukan preventive maintenance, yaitu dengan mengatur interval waktu perawatan. Interval waktu perawatan yang pendek dapat mencegah terjadinya breakdown, tetapi menimbulkan biaya perawatan yang tinggi. Sementara itu, interval waktu perawatan yang panjang akan menurunkan keandalan mesin, sehingga sering terjadi breakdown. Oleh karena itu perlu ditentukan interval waktu perawatan yang meminimumkan breakdown pada biaya perawatan yang rendah.

Pada kasus PT XYZ, perbaikan interval waktu perawatan dilakukan pada Lini produksi SPS yang lebih sering mengalami breakdown daripada lini produksi HOD. Lini produksi SPS, terdiri atas beberapa mesin untuk proses Blowing, Filling, Labelling dan Packaging. Apabila salah satu mesin mengalami kerusakan dan harus diperbaiki (breakdown), maka seluruh mesin pada lini produksi SPS akan berhenti beroperasi. Ketika berhenti beroperasi, dikatakan mesin mengalami downtime, yaitu waktu menganggur atau lama waktu mesin tidak dapat dijalankan untuk beroperasi sesuai yang diharapkan [1]. Berdasarkan wawancara dan observasi, apabila terjadi downtime selama 5 menit, PT XYZ dapat kehilangan produksi sebanyak 8,3\% dari seluruh produksi. Hal ini dapat menyebabkan target produksi tidak tercapai, bahkan perusahaan dapat kehilangan kesempatan untuk mendapatkan keuntungan yang ditargetkan.

Pada penelitian ini, perbaikan interval waktu perawatan difokuskan pada mesin Blowing dan mesin Filling karena kedua mesin ini merupakan mesin utama yang memiliki frekuensi kerusakan paling tinggi pada lini produksi SPS. Untuk kasus 2 mesin, penentuan interval waktu perawatan juga perlu mempertimbangkan apakah perawatan dilakukan secara terpisah atau digabung agar biaya perawatan minimum atau keandalan maksimum [2].

Pada studi ini, interval waktu perawatan sebagai upaya pencegahan (preventive maintenance) ditentukan dengan mengadopsi Model Age Replacement. Penentuan dilakukan dengan coba-coba pada berbagai interval waktu perawatan, kemudian dihitung expected downtime. Interval waktu perawatan dipilih untuk downtime paling kecil. Dengan demikian, selain dapat menentukan interval waktu, model Age Replacement juga dapat memprediksi lamanya downtime. 
Penentuan interval waktu perawatan dengan Model Age Replacement telah dilakukan antara lain untuk menentukan interval waktu perawatan pada komponen Bis [3], mesin multi block [4], mesin Volpack [5], komponen mesin pesawat terbang [6], dan komponen Cane Cutter I [7]. Pada penelitian ini, Model Age Replacement digunakan untuk menentukan interval waktu perawatan mesin Blowing dan Filling pada industri AMDK.

\section{Metodologi}

Perawatan (maintenance) merupakan suatu kombinasi dari setiap tindakan yang dilakukan untuk menjaga suatu mesin atau untuk memperbaikinya sampai suatu kondisi yang bisa diterima [8]. Proses perawatan mesin yang dilakukan oleh suatu perusahaan umumnya terbagi dalam dua bagian, yaitu perawatan terencana dan tidak terencana [9]. Perawatan dapat meningkatkan keandalan (reliability) yang didefinisikan sebagai probabilitas pada suatu barang, misalnya, produksi dan aset utilitas dan proses kerja, akan terus melakukan apa yang dibutuhkan pengguna tanpa kegagalan dalam kondisi yang telah ditentukan dalam periode waktu tertentu [10]

Langkah-langkah penentuan interval waktu perawatan diperlihatkan oleh Gambar 1.

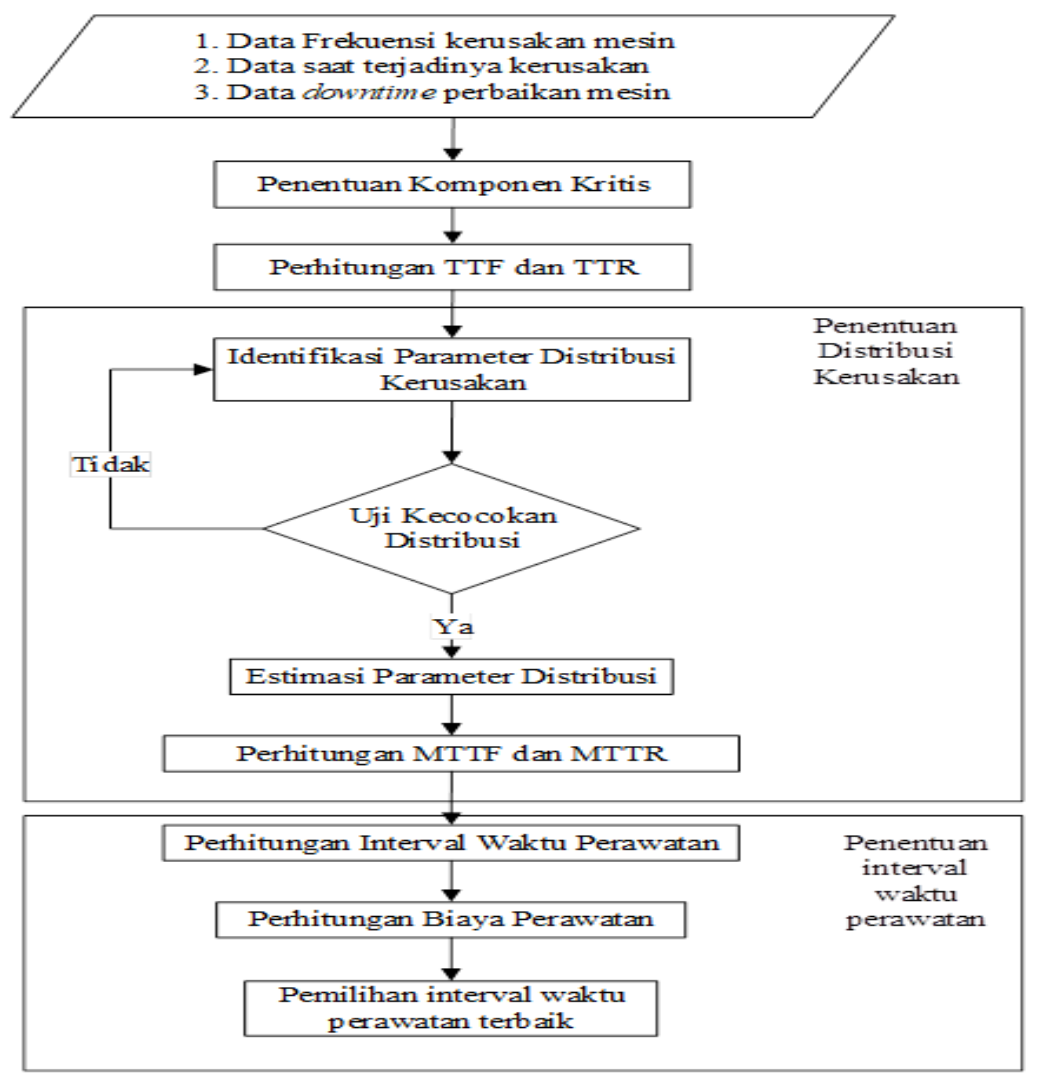

Gambar 1 Langkah-langkah penentuan interval waktu perawatan

\subsection{Penentuan Komponen Kritis}

Komponen kritis ditentukan dengan kriteria tingginya frekuensi kerusakan komponen dan pengaruhnya terhadap jalannya kegiatan produksi. Untuk menentukan komponen kritis diperlukan data tentang frekuensi terjadinya kerusakan mesin, saat terjadinya kerusakan, dan 
downtime perbaikan mesin. Data tersebut merupakan data sekunder yang dicari dengan studi dokumentasi. Berikutnya, komponen kritis yang terpilih dihitung Time to Failure (TTF) dan Time to Repair (TTR). TTF dihitung dari saat mesin dioperasikan hingga terjadinya kerusakan berikutnya, sedangkan TTR adalah lamanya waktu perbaikan.

\subsection{Penentuan Distribusi Kerusakan}

Teori Reliability digunakan untuk mencari nilai keandalan mesin dalam bentuk probabilitas. Tahap yang pertama adalah proses identifikasi pola distribusi. Tahap ini menggunakan Least Square Fitting dengan pendekatan empat distribusi yaitu Weibull, Lognormal, Normal dan Eskponensial untuk mencari nilai Index of Fit terbesar [11].

Distribusi kerusakan ditentukan oleh nilai Index of Fit terbesar, yang kemudian diuji dengan Goodness of Fit. Apabila hasil uji Goodness of Fit untuk Index of Fit terbesar tidak sesuai, maka uji Goodness of Fit dilakukan untuk Index of Fit terbesar kedua.

Selanjutnya dihitung Mean Time to Failure (MTTF) dan Mean Time to Repair (MTTR) yang dipengaruhi oleh distribusi yang sesuai dengan pola kerusakan mesin. MTTF menyatakan ekpektasi masa pakai sebuah alat yang dinyatakan sebagai rata-rata interval waktu terjadinya kerusakan, sedangkan MTTR merupakan rata-rata waktu perbaikan atau perawatan sebuah komponen [12].

\subsection{Penentuan Interval Waktu Perawatan dengan Model Age Replacement.}

Model Age Replacement bertujuan untuk menentukan usia optimal, $t_{p}$, di mana pencegahan penggantian harus terjadi sedemikian sehingga total downtime per satuan waktu dapat diminimumkan [2]. Adapun formulasi perhitungan untuk memperoleh downtime per satuan waktu adalah sebagai berikut:

$$
D_{\left(t_{p}\right)}=\frac{T_{p}\left(R_{\left(t_{p}\right)}\right)+T_{f}\left[1-R\left(t_{p}\right)\right]}{\left(t_{p}+T_{p}\right)+\left[M\left(t_{p}\right)+T_{f}\right]\left[1-R_{\left(t_{p}\right)}\right]}
$$

dengan:

$D_{\left(t_{p}\right)}=$ downtime per satuan waktu

$t_{p} \quad=$ interval waktu penggantian pencegahan per satuan waktu

$T_{p} \quad=$ waktu yang diperlukan untuk penggantian karena kerusakan.

$T_{f} \quad=$ downtime yang terjadi karena kegiatan penggantian.

$f_{(t)} \quad=$ fungsi distribusi interval waktu antar kerusakan.

$R_{\left(t_{p}\right)} \quad=$ keandalan terjadinya siklus $i$ pada saat $t_{p}$

$$
R_{\left(t_{p)}\right.}=e^{\left[-\left(\frac{t}{\theta}\right)^{\beta}\right]}
$$

$M_{\left(t_{p}\right)}=$ MTTF, jika penggantian dilakukan saat $t_{p}$.

$$
M_{\left(t_{p}\right)}=\frac{M T T F}{1-R\left(T_{p}\right)}
$$




\subsection{Perhitungan Biaya}

Biaya perawatan meliputi preventive cost dan failure cost. Preventive cost $\left(C_{p}\right)$ merupakan biaya untuk perawatan mesin yang sudah dijadwalkan, sedangkan failure cost $\left(C_{f}\right)$ merupakan biaya yang timbul karena terjadi kerusakan di luar perkiraan yang menyebabkan mesin produksi berhenti pada saat produksi sedang berjalan [13].

Adapun rumus untuk menghitung biaya perawatan adalah sebagai berikut:

$$
\begin{aligned}
& C_{f}=\left[\text { Biaya komponen }+(\text { Biaya teknisi }+ \text { biaya produksi }) T_{f}\right] \\
& C_{p}=\left[\text { Biaya komponen }+(\text { Biaya teknisi }+ \text { biaya produksi }) T_{p}\right]
\end{aligned}
$$

\section{Hasil dan Pembahasan}

\subsection{Hasil Perhitungan}

1) Penentuan Komponen Kritis

Komponen kritis didasarkan pada frekuensi kerusakan tertinggi, bentuk kerusakan yang fatal dan pengaruh seringnya perbaikan komponen terhadap downtime. Frekuensi kerusakan mesin ditunjukkan pada Tabel 1 untuk mesin Blowing, dan Tabel 2 untuk mesin Filling. Berdasarkan Tabel 1 dapat diketahui bahwa komponen kritis mesin Blowing adalah Sensor Sensitif, sedangkan komponen kritis mesin Filling adalah Rell Capper (lihat Tabel 2)

Tabel 1, Frekuensi kerusakan mesin Blowing

\begin{tabular}{llc}
\hline No & Komponen & Frekuensi \\
\hline 1 & Sensor Sensitif & 69 \\
2 & Spindle Unit & 5 \\
3 & Mold SBO & 19 \\
4 & Preform conveying & 29 \\
& Table & \\
5 & Selang chiller & 1 \\
6 & Ejector & 6 \\
7 & Rel Preform & 8 \\
8 & Griper Unit & 2 \\
9 & Blowing Sistem & 8 \\
10 & Opening Closing & 2 \\
& System & 5 \\
11 & Oven Unit & 4 \\
12 & Elevator & 158 \\
\hline Jumlah & \\
\hline
\end{tabular}

Tabel 2. Frekuensi kerusakan mesin Filling

\begin{tabular}{llc}
\hline No & Komponen & Frekuensi \\
\hline 1 & Rell Capper & 21 \\
2 & Filling Unit & 4 \\
3 & Valve Braket & 4 \\
4 & Capper Unit & 8 \\
5 & Star Wheel & 3 \\
6 & Conveyor & 6 \\
& In/Out & \\
\hline Total & & 46 \\
\hline
\end{tabular}

2) Identifikasi Pola Distribusi dan Kecocokan data.

Hasil identifikasi pola distribusi dapat dilihat pada Tabel 3. 
Tavel 3 Rekapitulasi identifikasi pola distribusi

\begin{tabular}{lllcccc}
\hline \multirow{2}{*}{ Mesin } & \multirow{2}{*}{ Komponen } & Data & & \multicolumn{4}{c}{ Nilai Index of fit } \\
\cline { 4 - 7 } & & $\begin{array}{l}\text { Distribusi } \\
\text { Weibull }\end{array}$ & $\begin{array}{l}\text { Distribusi } \\
\text { Lognormal }\end{array}$ & $\begin{array}{c}\text { Distribusi } \\
\text { Normal }\end{array}$ & $\begin{array}{l}\text { Distribusi } \\
\text { Eksponensial }\end{array}$ \\
\hline \multirow{2}{*}{ Blowing } & Sensor & TTR & 0,888 & 0,959 & 0,731 & 0,027 \\
& Sensitif & TTF & 0,831 & 0,918 & 0,845 & 0,029 \\
\hline \multirow{2}{*}{ Filling } & Rell & TTR & 0,985 & 0,979 & 0,958 & 0,958 \\
& Capper & TTF & 0,935 & 0,963 & 0,85 & 0,954 \\
\hline
\end{tabular}

3) Hasil Uji kecocokan data dan Estimasi parameter

Setelah didapat hasil identifikasi pola distribusi, maka selanjutnya adalah melakukan uji kecocokan data. Pada Tabel 3 dapat dilihat bahwa index of fit terbesar untuk TTF dan TTR komponen Sensor Sensitif keduanya sesuai dengan Distribusi Lognormal, sedangkan index of fit terbesar untuk TTF dan TTR komponen Rell Capper secara berturut-turut sesuai dengan Distribusi Weibull dan Distribusi Lognormal. Namun, uji Goodness of Fit menunjukkan bahwa pola TTR dan TTF untuk komponen Sensor Sensitif dan Rell Cepper semuanya sesuai dengan Distribusi Weibull.

Selanjutnya, ditentukan parameter TTF dan TTR yang sesuai dengan distribusi Weibull. Rekapitulasi estimasi parameter distribusi Weibull dapat dilihat pada Tabel 4.

Tabel 4 Hasil Uji kecocokan data dan estimasi parameter

\begin{tabular}{|c|c|c|c|c|c|c|c|c|c|}
\hline \multirow[b]{2}{*}{ No } & \multirow{2}{*}{ Mesin } & \multirow{2}{*}{ Komponen } & \multirow{2}{*}{$\begin{array}{l}\text { Hasil Uji } \\
\text { kecocokan } \\
\text { data }\end{array}$} & \multicolumn{3}{|c|}{ Parameter TTF } & \multicolumn{3}{|c|}{ Parameter TTR } \\
\hline & & & & $\alpha$ & $\beta$ & $\theta$ & $\alpha$ & $\beta$ & $\theta$ \\
\hline 1 & Blowing & $\begin{array}{l}\text { Sensor } \\
\text { sensitif }\end{array}$ & Weibull & $-5,91$ & 1,44 & 61,42 & 0,26 & 0,45 & 0,55 \\
\hline 2 & Filling & Rell Capper & Weibull & $-5,34$ & 1,08 & 143,74 & 3,23 & 1,50 & 0,12 \\
\hline
\end{tabular}

\section{4) Perhitungan MTTF dan MTTR}

Setelah dilakukan uji kecocokan data dan estimasi parameter disribusi terpilih, maka selanjutnya adalah menghitung nilai MTTF dan MTTR. Rekapitulasi perhitungan MTTF dan MTTR dapat dilihat pada Tabel 5 .

Tabel 5. Rekapitulasi Perhitungan MTTF \& MTTR

\begin{tabular}{lllc}
\hline Mesin & Komponen & $\begin{array}{l}\text { MTTR } \\
\text { (jam) }\end{array}$ & $\begin{array}{l}\text { MTTF } \\
\text { (jam) }\end{array}$ \\
\hline $\begin{array}{l}\text { Blowing } \\
\text { Filling }\end{array}$ & $\begin{array}{l}\text { Sensor sensitif } \\
\text { Rell Capper }\end{array}$ & 1,40 & 55,77 \\
\hline
\end{tabular}

5) Penentuan interval waktu perawatan dengan Model Age Replacement

- Komponen Sensor Sensitif pada mesin Blowing

Interval waktu perawatan ditentukan dengan cara trial \& error menggunakan Model Age Replacement sampai didapatkan nilai downtime terkecil. 
Untuk $\beta=1,44 ; \theta=61,42=3.685,17$ menit (lihat Tabel 4); $\mathrm{MTTF}=55,77 \mathrm{jam}=$ 3.346,10 menit; $T_{f}=$ MTTR = 1,40 jam = 84 menit (lihat Tabel 5); $T_{p}=60$ menit, maka dengan menggunakan Persamaan (2) diperoleh keandalan $\left(R_{\left(t_{p)}\right)}\right)$ komponen Sensor Sensitif pada mesin Blowing adalah

$$
R_{\left(t_{p)}\right.}=e^{-\left(\frac{t}{\theta}\right)^{\beta}} e^{\left\{-\left(\frac{3.346}{3.685,17}\right)^{1,44}\right]}=0,419
$$

Nilai $M_{\left(t_{p}\right)}$ ditentukan dari Persamaan (3) dan hasilnya adalah

$$
M_{\left(t_{p)}\right.}=\frac{M T T F}{1-R_{(t p)}}=\frac{3.346,10}{0,581}=5.756,4
$$

Dengan demikian, downtime per satuan waktu $\left(D_{\left(t_{p)}\right.}\right)$ komponen Sensor Sensitif pada mesin Blowing dihitung dengan menggunakan Persamaan (1) dan diperoleh

$$
D_{\left(t_{p}\right)}=\frac{T_{p}\left(R_{\left(t_{p}\right)}\right)+T_{f}\left[1-R\left(t_{p}\right)\right]}{\left(t_{p}+T_{p}\right)+\left[M\left(t_{p}\right)+T_{f}\right]\left[1-R_{\left(t_{p}\right)}\right]}=\frac{60(0,419)+84[0,581)]}{(3.346+60)+[0,581+84][0,581]}=0,0153
$$

Rekapitulasi perhitungan untuk menentukan interval waktu perawatan dengan Model Age Replacement dapat dilihat pada Tabel 6.

Tabel 6. Interval waktu perawatan $\left(t_{p}\right)$ dan downtime $\left(D_{\left(t_{p}\right)}\right)$ komponen Sensor Sensitif

\begin{tabular}{rlrrl}
\hline$t_{p}$ (menit) & $R_{\left(t_{p)}\right.}$ & $1-R_{\left(t_{p)}\right.}$ & \multicolumn{1}{c}{$M_{\left(t_{p)}\right.}$} & $D_{\left(t_{p}\right)}$ \\
\hline 60 & 0,9972 & 0,0027 & $1.237 .253,4$ & 0,0173 \\
120 & 0,9927 & 0,0072 & $458.453,4$ & 0,0170 \\
180 & 0,9869 & 0,0130 & $256.891,0$ & 0,0168 \\
1.800 & 0,6994 & 0,3005 & $11.132,7$ & 0,0143 \\
$* 1.860$ & 0,6874 & 0,3125 & $10.707,0$ & 0,0143 \\
2.040 & 0,6519 & 0,3480 & $9.612,7$ & 0,0144 \\
3.300 & 0,4259 & 0,5740 & $5.828,9$ & 0,0152 \\
$* * 3.346$ & 0,4187 & 0,5812 & $5.756,4$ & 0,0153 \\
\hline
\end{tabular}

Keterangan: *interval waktu perbaikan kondisi usulan **MTTF kondisi eksisting

- Komponen Rell Capper pada mesin Filling

Untuk $\beta=1,08 ; \theta=143,74=8.624,27$ menit (lihat Tabel 4);

$\mathrm{MTTF}=139,76 \mathrm{jam}=8.385,7$ menit; $T_{f}=\mathrm{MTTR}=0,10 \mathrm{jam}=6$ menit (lihat Tabel 5); $T_{p}=6,19$ menit, maka keandalan $\left(R_{\left(t_{p)}\right.}\right)$ dan $M_{\left(t_{p}\right)}$ komponen Rell Capper pada mesin Filling adalah

$$
R_{\left(t_{p)}\right.}=e^{-\left(\frac{t_{\theta}}{\beta}\right)^{\beta}} e^{\left\{-\left(\frac{8.385}{8624,27}\right)^{1,08}\right]}=0,3790
$$




$$
M_{\left(t_{p)}\right.}=\frac{M T T F}{1-R_{\left(t_{p)}\right.}}=\frac{8385}{0,6210}=13.502,4
$$

Dengan demikian, downtime per satuan waktu $\left(D_{\left(t_{p}\right)}\right)$ komponen Rell Capper pada mesin Filling yang dihitung dengan menggunakan Persamaan (1) adalah

$$
D_{\left(t_{p}\right)}=\frac{6,19(0,3790)+6[0,6210)]}{(8624,27+6)+[0,6210+6,19][0,6210]}=0,0007030
$$

Rekapitulasi penentuan interval waktu perawatan menggunakan Model Age Replacement untuk mesin Filling dapat dilihat pada Tabel 7.

Tabel 7. Interval waktu perawatan $\left(t_{p}\right)$ dan downtime $\left(D_{\left(t_{p}\right)}\right)$ komponen Rell Capper

\begin{tabular}{rlrrc}
\hline$t_{p}$ (menit) & $R_{\left(t_{p)}\right.}$ & $1-R_{\left(t_{p)}\right.}$ & \multicolumn{1}{c}{$M_{\left(t_{p)}\right.}$} & $D_{\left(t_{p}\right)}$ \\
\hline 60 & 0,9952 & 0,0047 & $1.757 .718,9$ & 0,000732 \\
120 & 0,9899 & 0,0100 & $836.283,5$ & 0,000727 \\
180 & 0,9845 & 0,0154 & $542.211,6$ & 0,000722 \\
1.860 & 0,8252 & 0,1747 & $47.980,4$ & 0,000625 \\
2.460 & 0,7714 & 0,2285 & $36.691,2$ & 0,000603 \\
2.520 & 0,7662 & 0,2337 & $35.869,2$ & 0,000601 \\
$* 7.980$ & 0,3985 & 0,6014 & $13.942,8$ & 0,000539 \\
8.040 & 0,3956 & 0,6043 & $13.874,6$ & 0,000540 \\
8.100 & 0,3926 & 0,6073 & $13.807,6$ & 0,000540 \\
$* * 8.385$ & 0,3790 & 0,6210 & $13.502,4$ & 0,000703 \\
\hline
\end{tabular}

Keterangan: *interval waktu perbaikan kondisi usulan **MTTF kondisi eksisting

Berdasarkan Tabel 6 dan Tabel 7, didapat interval waktu perawatan untuk mesin Blowing adalah setiap 1.860 menit setara dengan 31 jam. Interval waktu perawatan untuk mesin Filling adalah setiap 7.980 menit setara dengan $131 \mathrm{jam}$. Dari perbedaan waktu perawatan tersebut maka ada tiga alternatif yang dapat dipilih untuk diimplementasikan, yaitu:

a. Perawatan mesin Filling dimajukan dan dilakukan bersamaan dengan perawatan mesin Blowing.

b. Perawatan dilakukan secara masing-masing sesuai dengan jadwal yang telah dibuat.

c. Perawatan mesin Blowing dimundurkan dan dilakukan bersamaan dengan mesin Filling.

6) Perhitungan Biaya

Apabila diasumsikan pada kegiatan preventif tidak terjadi pergantian komponen, hasil perhitungan biaya perawatan dapat dilihat pada Tabel 8 . 
Tabel 8. Perhitungan Biaya

\begin{tabular}{lllllll}
\hline Komponen & $\begin{array}{l}\text { Biaya } \\
\text { Teknisi/ } \\
\text { jam (Rp) }\end{array}$ & $\begin{array}{l}\text { Biaya } \\
\text { Produksi/ } \\
\text { jam (Rp) }\end{array}$ & $\begin{array}{l}T_{p} \\
(\mathrm{jam})\end{array}$ & $\begin{array}{l}T_{f} \\
(\mathrm{jam})\end{array}$ & $C_{p}(\mathrm{Rp})$ & $C_{f}(\mathrm{Rp})$ \\
\hline & & & & & \\
\hline Sensor sensitif & 255.208 & 19.600 .000 & 1 & 1,4 & 19.855 .208 & 27.797 .291 \\
Rell Capper & 255.208 & 19.600 .000 & 0,1 & 0,103 & 1.985 .521 & 92.045 .086 \\
\hline
\end{tabular}

\subsection{Pembahasan}

Berdasarkan frekuensi kerusakan mesin, lini SPS lebih sering mengalami kerusakan daripada lini produksi HOD. Pada lini SPS, terdapat 2 mesin utama yang memiliki frekuensi kerusakan paling tinggi yaitu mesin Blowing dan mesin Filling. Komponen kritis pada mesin Blowing - yang ditunjukkan dari frekuensi kerusakan paling tinggi - adalah Sensor Sensitif (Tabel 1), sedangkan komponen kritis pada mesin Filling adalah Rell Capper (Tabel 2). Berdasarkan uji dengan metode Least Square, dan uji kesesuaian dengan metode Goodness of Fit diperoleh bahwa pola kerusakan dan rata-rata waktu perbaikan baik komponen Sensor Sensitif maupun komponen Rell Capper sesuai dengan distribusi Weibull (Tabel 4).

Tabel 5 menunjukkan nilai MTTF dan MTTR komponen Sensor Sensitif dan Rell Capper pada kondisi eksisting, sedangkan Tabel 6 dan 7 secara berturut-turut menunjukkan hasil perhitungan reliability, maintanability dan downtime kondisi eksisting. Pada Tabel 6 ditunjukkan bahwa pada MTTF sebesar 55,77 jam atau 3.345 menit, Sensor Sensitif pada kondisi eksisting memiliki keandalan sebesar $41 \%$ dan membutuhkan rata-rata waktu untuk perbaikan sebesar 84 menit atau 1,4 jam. Tabel 7 menunjukkan bahwa MTTF komponen Rell Capper kondisi esksisting adalah sebesar 8.385 menit atau 139,76 jam dengan nilai keandalan 37,9\% dan membutuhkan rata-rata waktu untuk perbaikan mesin sebesar 6,19 menit atau 0,10 jam. Berdasarkan hasil pengamatan secara langsung, rendahnya nilai keandalan disebabkan oleh beberapa faktor yang mempengaruhi diantaranya adalah, beban kerja mesin, komponen, bahan baku, metode, pekerja dan lingkungan. Faktor komponen memberi kontribusi paling banyak atas rendahnya keandalan, karena komponen yang digunakan merupakan hasil modifikasi perusahaan dan bukan Original Equipment Manufacturing (OEM).

Pada Tabel 6 ditunjukkan bahwa dengan Model Age Replacement diperoleh interval waktu perawatan usulan untuk komponen Sensor Sensitif pada downtime minimum adalah setiap 1.860 menit atau setiap 31 jam dengan nilai keandalan sebesar 74\%, sedangkan untuk komponen Rell Capper adalah setiap 7.980 menit atau setiap 131 jam dengan nilai keandalan sebesar 39,85\%, sebagaimana ditunjukkan pada Tabel 7.

Perawatan mesin Blowing dan Filling dapat dilakukan secara terpisah maupun digabung, sehingga terdapat tiga alternatif yang dapat diterapkan untuk kegiatan perawatan, yaitu:

Alternatif 1: Perawatan mesin Filling dimajukan dan dilakukan bersamaan dengan perawatan mesin Blowing. 
Alternatif 2: Perawatan dilakukan secara masing-masing sesuai dengan jadwal yang telah dibuat. Penerapan alternatif ini akan membuat frekuensi perawatan akan bertambah karena adanya perbedaan waktu perawatan.

Alternatif 3: Perawatan mesin Blowing dimundurkan dan dilakukan bersamaan dengan mesin Filling. Penerapan alternatif ini tidak mungkin dilakukan karena pada dasarnya mesin Blowing memiliki rata-rata waktu antar kerusakan yang lebih pendek. Jika tetap diterapkan, maka akan menambah kemungkinan akan terjadinya kerusakan mesin yang tinggi walaupun estimasi lama perawatan akan lebih rendah

Ketiga alternatif tersebut memiliki konsekuensi masing-masing. Konsekuensi dari penerapan ketiga alternatif adalah sebagai berikut:

a. Konsekuensi dari alternatif pertama adalah interval waktu perawatan mesin Filling akan menjadi pendek dan menyebabkan frekuensi perawatan akan tinggi. Namun disisi lain, alternatif ini dapat meningkatkan nilai keandalan mesin. Bila alternatif ini diterapkan, maka akan ada 5 kali kegiatan perawatan untuk satu minggu mengikuti interval waktu perawatan mesin Blowing.

b. Penerapan alternatif kedua adalah lama waktu untuk kegiatan perawatan yang akan bertambah yang menimbulkan kerugian produksi yang lebih banyak. Bila alternatif ini diterapkan, maka akan ada 6 kali kegiatan perawatan untuk satu minggu.

c. Penerapan alternatif ketiga adalah interval waktu perawatan mesin Blowing akan lebih panjang. Penerapan alternatif ini dapat menurunkan nilai keandalan mesin sehingga kemungkinan kerusakan mesin akan tinggi. Bila alternatif ini diterapkan, maka akan ada 1 kali kegiatan perawatan dalam satu minggu mengikuti interval waktu perawatan mesin Filling.

Perbandingan biaya untuk masing-masing alternatif dapat dilihat pada Tabel 9.

Tabel 9. Perbandingan biaya masing-masing alternatif

\begin{tabular}{|c|c|c|c|c|c|c|}
\hline \multirow[b]{2}{*}{ Alternatif } & \multirow{2}{*}{$\begin{array}{l}\text { Biaya } \\
\text { teknisi } \\
\text { /jam } \\
\text { (Rp) }\end{array}$} & \multirow{2}{*}{$\begin{array}{l}\text { Biaya } \\
\text { produksi/jam } \\
\text { (Rp) }\end{array}$} & \multirow{2}{*}{$\begin{array}{l}\text { Frekuensi } \\
\text { perawatan } \\
\text { /minggu } \\
\text { (jam) }\end{array}$} & \multirow[b]{2}{*}{$\begin{array}{l}\text { Total Biaya } \\
\text { (Rp) }\end{array}$} & \multicolumn{2}{|c|}{ Nilai keandalan } \\
\hline & & & & & $\begin{array}{l}\text { Mesin } \\
\text { Blowing }\end{array}$ & $\begin{array}{l}\text { Mesin } \\
\text { Filling }\end{array}$ \\
\hline 1 & 255.208 & 10 & 5 & & 68 & $82 \%$ \\
\hline 2 & 255.2 & 19.60 & 6 & 11 & $68 \%$ & $39 \%$ \\
\hline 3 & 255.208 & 19.600 .000 & 1 & 19.855 .208 & $5 \%$ & $39 \%$ \\
\hline
\end{tabular}

Dalam segi biaya yang harus dikeluarkan, maka alternatif ke tiga merupakan yang terbaik berdasarkan biaya yang paling rendah. Namun alternatif ke tiga tidak dapat diterapkan mengingat bahwa faktor yang dipertimbangkan dalam pemilihan alternatif bukan hanya dari segi biaya tetapi juga dari nilai keandalan mesin. Alternatif ke dua tidak dipilih karena biaya lebih mahal dan waktu perwatan lebih lama. Dengan demikian alternatif yang dipilih adalah yang ke satu, walaupun dalam segi biaya bukan merupakan yang paling rendah, namun alternatif ini efektif dalam segi waktu dan dapat mempertahankan nilai keandalan pada mesin, sehingga kemungkinan terjadinya kerusakan mesin dapat diminimalkan. 
Jika dibandingkan antara kondisi eksisting dan kondisi usulan, dapat dilihat bahwa interval perawatan usulan akan meningkatkan keandalan sebesar 26,2\% (dari 41,8\% menjadi 68\%) untuk komponen Sensor Sensitif, dan 44,1 \% (dari 37,9 menjadi 82\%) untuk komponen Rell Capper.

\section{Kesimpulan}

Berdasarkan perhitungan dan pembahasan dapat disimpulkan bahwa tingginya frekuensi kerusakan mesin dapat disebabkan oleh rencana perawatan yang tidak tepat. Kegiatan perawatan yang dilakukan secara bersamaan dapat menghindarkan banyaknya waktu terbuang karena kegiatan perawatan. Penentuan interval waktu perawatan dengan Model Age Replacement dapat menurunkan lama waktu downtime, sehingga menaikkan keandalan.

Pada kasus PT XYZ, terdapat dua mesin yang memiliki frekuensi kerusakan tertinggi yaitu mesin Blowing dengan komponen kritis Sensor Sensitif, dan mesin Filling dengan komponen kritis Rell Capper. Perhitungan menunjukkan bahwa interval waktu perawatan usulan adalah 31 jam untuk komponen Sensor Sensitif dan 131 jam untuk komponen Rell Capper. Perawatan kedua mesin dapat dilakukan secara terpisah atau digabung. Berdasarkan perhitungan, diusulkan bahwa perawatan mesin Filling pada siklus ke-5 dimajukan dan dilakukan bersama-sama dengan mesin Filling karena memberikan keandalan paling tinggi, walaupun biayanya bukan yang paling murah. Gabungan perawatan ini dapat meningkatkan keandalan mesin Blowing sebesar 26,2\% dan mesin Filling sebesar 44,1\%.

Selain menggunakan Teori Reliability, penentuan interval waktu perawatan dapat dilakukan dengan metode lainnya, misalnya Total Productive Maintenance (TPM) dan Reliability Centered Maintenance (RCM). Hal ini dapat dilakukan sebagai penelitian lanjutan (futher research)

\section{Daftar Pustaka}

[1] J.V.R. Picknell, dan J.R. Sifonte, 2017. Reliability Centered Maintenance-Reengineered: Practical Optimization of the RCM Process with RCM-R. New York: CRC Press

[2] A. K. S. Jardine dan A. H. C. Tsang, "Maintenance, replacement and reliability,". 2nd . ed . Boca Raton: Taylor \& Francis Group, 2013, e-book.

[3] J. Purnama, Y. A. Putra, dan M. Kalamollah, "Metode Age Replacement Digunakan untuk Menentukan Interval Waktu Perawatan Mesin pada Armada Bus", Seminar Nasional Sains dan Teknologi Terapan III, 13 Oktober 2015, editor: S. Syamsuri, Institut Teknologi Adhi Tama Surabaya (ITATS), Surabaya, Indonesia, 2015, pp. 115 - 126.

[4] M. Hariadi, "Penentuan Interval Waktu Penggantian Komponen Kritis pada Mesin Multi Block Menggunakan Metode Age Replacement (Studi Kasus Di CV. Walet Sumber Barokah)", Tugas Akhir, Universitas Muhammadiyah Malang, Malang, Jawa Timur, Indonesia, 2017.

[5] Y. Y. Prawiro, "Penentuan Interval Waktu Penggantian Komponen Kritis pada Mesin Volpack Menggunakan Metode Age Replacement", Jurnal Teknik Industri, vol. 16, no. 2, pp. 92-100, 2015.

[6] R. Wahyuniardi, Arumsari H., R. Triana, "Penentuan Interval Perawatan dengan Menggunakan Model Age Replacement di PT. "X", Prosiding Seminar Nasional Mesin dan Industri (SNMI X), Jakarta, 21-22 April 2016, editor: A.P. Irawan, Prodi Teknik Mesin dan Teknik Industri, Universitas Tarumanagara, Jakarta, 2016, pp. TI-174 - TI-181. 
[7] S. D. Mutiara, A. Rahman, dan I. Hamdala, "Perencanaan Preventive Maintenance Komponen Cane Cutter I dengan Pendekatan Age Replacement (Studi Kasus di PG Kebon Agung Malang)", Jurnal Rekayasan dan Manajemen Sistem Industri, vol 2, no 2, pp. 396405, 2014.

[8] A. S. Corder, "Maintenance Management Techniques," diterjemahkan dari bahasa Inggris Oleh Hadi, K., 1988. Jakarta: Penerbit Erlangga.

[9] S.O., Duffua dan A. Raouf, 2015, "Planning and control of maintenance Systems," 2nd. ed. Switzterland: Springer, e-boook.

[10] K.R. Mobley, L.R. Higgins, dan D.J. Wikkof, "Maintenance Engineering Handbook”, 7th. ed. New York : Mcgraw Hill <http://gen.lib.rus.ac>. 2008 e-book.

[11] C.E. Ebeling, "An Introduction To Reliability And Maintainability Engineering”. 3ed. Edition. Long Grove: Waveland Press Inc, 2019..

[12] N. Ansori dan M.I. Mustajib, "Sistem Perawatan Terpadu," Yogyakarta: Graha Ilmu, 2013.

[13] I., Soesetyo dan L. Y. Bendatu, "Penjadwalan predictive maintenance dan biaya perawatan mesin pallet di PT. Chaeron Pokphand Indonesia- Sepanjang," Jurnal Teknik Industri, vol 2, no. 2, pp.147-154, 2014. 